\title{
Effects of reducing EU agricultural support payments on production and farm income in Finland
}

\author{
Heikki Lehtonen and Jyrki S. Niemi \\ Bioeconomy and Environment, Natural Resources Institute Finland (Luke) \\ e-mail: heikki.lehtonen@luke.fi
}

\begin{abstract}
The budget for the Common Agricultural Policy (CAP) of the EU, and thus EU agricultural support payments, may be reduced from 2021. In this study we analyse the effects this may have in Finland using an economic model of Finnish agriculture accounting for structural changes in the dairy and beef sectors. Reducing the CAP budget by $20 \%$ would affect farm incomes by $20-25 \%$ in southern Finland while central and northern parts of the country, which are dependent on national payments coupled to dairy and beef production, would be less affected. Our results show that the milk and beef sectors throughout the country are still dependent on support payments coupled to production due to reduced real prices for agricultural products. Current policy schemes for southern Finland include coupled CAP payments but do not allow national payments. Any cuts in the CAP budget have significantly more negative effects in southern Finland compared to other regions.
\end{abstract}

Key words: agricultural policy, agricultural economics, decoupled payments, sector modelling, structural change

\section{Introduction}

There is a real possibility that EU agricultural support payments for farmers will decrease in the next Multiannual Financial Framework (MFF) period, taking effect from 1 January 2021, compared to the 2014-2020 period. There are various pressures on shifting budget resources from agriculture and rural development to other sectors, especially those which are considered more crucial to the competitiveness of the EU economies due to developments of the global economy. There are also significant new challenges, especially with respect to migration and security that require resources in the EU (Matthews 2017). The departure of the United Kingdom will add to these pressures if it leaves a hole in the EU budget (the UK is the second largest net contributor to the budget after Germany), although this will depend, in part, on the terms of the 'divorce settlement' agreed as part of the Brexit negotiations (Niemi and Matthews 2017). Haas and Rubio (2017) and Matthews (2017) estimated that Brexit will leave a permanent shortfall of $€ 10.2$ billion per year in the EU budget. This gap has to be filled either through higher national contributions, spending cuts, or a combination of both. Haas and Rubio (2017) further estimated that the British net financial contribution under the CAP amounts to $€ 3$ billion annually. However, spending cuts after Brexit could exceed that sum if other EU programmes are prioritized. Adjusting to the Brexit gap only through CAP spending cuts (that is, cutting CAP by $€ 10$ billion), would cut CAP expenditure by about $20 \%$.

Studies on the effects of reducing EU farm budget are relatively few in recent years. Boulanger and Philippidis (2015) found very small effects on agricultural production resulting from large EU farm budget cuts $(-50 \%)$ in the EU 28, as well as in several member states. Due to the small production effects the effects of such cuts on prices and international trade were found to be relatively small (just few percents). However, the effects of EU CAP budget cuts on farm incomes were significant in individual member states. The effects in Finland were not reported. In this paper we evaluate to what extent possible cuts in the EU agricultural budgets are likely to impact agriculture in Finland, which is clearly a less favoured agricultural production region in the EU. There are certain national aims to maintain agricultural and food production in Finland for food security reasons and for potential crisis situations (Finnish Government 2013, Ministry of Agriculture and Forestry 2017).

Agricultural support payments for farmers in the EU are largely decoupled from production. The support should not provide primary incentives for agricultural production and necessary farm investments. According to the EU CAP policy on farm subsidies, incentives for production should come primarily from the markets, not from farm subsidies. Agricultural support in the EU is primarily intended as income support paid to farmers and to keep farmland areas in good agricultural condition (EC 2003, EC 2013).

Nevertheless, agricultural support payments coupled to production are important in less favoured areas such as Finland, where crop yields are low and production costs are high due to climatic factors, topography and soil types. Cereal yields in Finland are 3.5 tons ha-1 ${ }^{-1}$ on the average while $6-9$ tons ha- ${ }^{-1}$ are harvested widely in Western Europe (Eurostat 2017). 
Earlier studies on the effects of the CAP reform on Finnish agriculture have shown agricultural production to be dependent on EU and national payments coupled to milk and beef production (Lehtonen 2004, Pietola and Heikkilä 2005). If these payments coupled to production do not continue, the profitability of beef and dairy investments will decline (Ridier and Jacquet 2002). This may reduce investments, even in larger and more efficient farms, and reduce aggregate production (Lehtonen 2004).

Support for Finnish agriculture under the CAP totalled $€ 1,377$ million 2017. This consists of CAP pillar 1 payments for arable crops and livestock ( $€ 525$ million), and pillar 2 payments for less-favoured areas (LFAs) (€ 552 million), and agri-environmental payments ( $€ 300$ million). The CAP pillar 1 payments are funded in full from the EU budget. For the pillar 2 payments, the EU contributes less than 20\% of the LFA and more than $40 \%$ of the agri-environmental payments. The rest is paid from national funds (Niemi and Väre 2017).

Besides the EU (co-)financed support, in 2017 about $€ 330$ million was paid to Finnish farms as national aid. The national aid scheme comprises northern aid ( $€ 297$ million), aid for southern Finland ( $€ 25$ million), and other national aid programmes ( $€ 8$ million). The national payments are largely coupled to production based on: litres of milk (approx. $€ 160$ million per annum), heads of animals, and hectares of oilseed and protein crops (Niemi and Väre 2017). These are permanent since they are specified in the EU accession treaty of Finland, while similar national payments are not allowed in southern Finland (EU 1994). This is the reason why most EU payments coupled to production are paid in southern Finland, support regions AB (Niemi and Väre 2017).

Overall, Finland pays $56 \%$ of the necessary support for agriculture from its national funds, while less than $44 \%$ comes from the EU agriculture budget 2014-2020. The share of payments coupled to production out of the total amount of the pillar 1 CAP support payments was given an upper limit of $20 \%$ in 2015 . This limit will fall slightly to $19.6 \%$ towards the end of the 2014-2020 period (EC 2017). Most of the EU support coupled to production is paid per head of bovine animals, per hectare of protein and oilseed crops and for some other crops in southern Finland. Similar payments are carried out in central and northern Finland from national funds according to specific limits and rules approved by the European Commission (Niemi and Väre 2017). Hence the national payments, according to current legislation (EU 1994), cannot be increased to compensate for cuts in EU funded support payments, especially in southern Finland where no national payments coupled to beef or milk production or individual crops are allowed. Thus, there is an obvious possibility that any cuts in EU funded support payments will reduce agricultural income and production in southern Finland compared to farmers in central and northern Finland where the role of EU funded support payments is relatively smaller.

The aim of this study is to evaluate 1) to what extent agricultural production and farm incomes in Finland, in southern Finland and elsewhere in the country, will be affected by significant reductions in EU CAP farm support payments; 2) to what extent agricultural production and farm incomes in Finland are still dependent on EU CAP and national payments coupled to production. Overall, we evaluate the importance of EU CAP payments for Finnish agriculture. Since EU CAP payments consist of support payments both decoupled from production and payments coupled to production it is relevant to analyse to what extent reductions in coupled payments affect agricultural production. Based on previous literature (Dewbre et al. 2001, Lehtonen 2004, Pietola and Heikkilä 2005, Balkhausen et al. 2008), we expect that coupled and decoupled payments will have different effects on agricultural production and income.

We compare the production and income effects of the following policy options, if implemented in 2021: (1) A reduction in the EU contribution to agricultural support payments by 20\%; (2) All CAP pillar 1 payments decoupled from production; (3) A reduction in national payments by $20 \%$.

The effects of these policy options are compared to the baseline assuming a continuation of the 2014-2020 CAP. These policy options are used in order to evaluate the significance and importance of possible EU CAP budget cuts in Finland, not to anticipate or estimate the likelihood of any future policy options that will realise. The policy effects are also compared to the effects of two market scenarios, implemented on the top of the baseline. These include either a small, or a significant reduction in prices of agricultural products from 2021.

This paper proceeds as follows. First, we specify the scenarios in more detail. After that we introduce the main characteristics of the economic agricultural sector model DREMFIA. Then we present and discuss the main results at the overall national level and for the $A B$ support region (southern Finland) and the $C$ support region (central and northern Finland). Finally, some conclusions, including implied message to policy makers, are presented. 


\section{Methods \\ Policy scenarios}

The baseline scenario

In this "business as usual" scenario, unchanged crop yields and the agricultural policy of 2015-2016 are assumed. The future prices for agricultural outputs are assumed as EU prices projected by the OECD-FAO agricultural outlook 2016 (www.agri-outlook.org). An unchanged 2016 policy is assumed for the $2017-2030$ period. $80 \%$ of CAP pillar 1 payments (approx. $€ 550$ million annually in Finland) are paid on a per hectare basis, decoupled from crop choice and production.

In the baseline scenario, payments for less favoured areas (LFAs) are paid on a per hectare basis irrespective of crop choice, but they include higher payments for livestock farms compared to crop farms. Agri-environmental payments aimed at water protection and biodiversity conservation effectively restrict fertilization levels. In total, CAP pillar 2 payments (LFA and agri-environmental payments combined) amount to $€ 800$ million annually.

Close to $20 \%$ of the CAP pillar 1 payments are coupled to production in this baseline scenario. Coupled CAP payments are paid as dairy cow premiums (approx. $€ 550$ /head in $A B$ support regions), bull premiums (approx. $€ 500$ /head; $€ 170$ /head in C support regions), and suckler cow premiums (approx. $€ 430$ /head in AB support regions, or $€ 180$ /head in C support regions), and as per hectare payments for protein crops and oilseed crops (approx. $€$ 14 million) annually throughout the whole country.

Nordic Aid, standing at approximately $€ 300$ million per annum, is fully paid from the national state budget, according to the regulations approved at EU level, in the baseline scenario. This provides milk and beef payments, as well as some minor crop-specific payments in support regions C (at different levels in C1, C2, C2P, C3, and C4 support regions). As part of the Nordic Aid scheme, milk payments in C support regions are 7-14 cents litre ${ }^{-1}$. There are separate budgetary constraints for milk and beef payments in support regions $A B$, and $C$, respectively. This means that the support paid per unit decreases with increasing production. The aim of the payments coupled to production is to maintain existing, historical production levels in AB- and C-support regions separately, without leading to production expansion. A more detailed presentation of the support payments is given in Niemi and Väre (2017). Domestic demand for agricultural products remains at the 2015-2016 in the baseline.

Policy scenario 1 - A reduction in the EU contribution to agricultural support payments by $20 \%$

$$
\text { (Cut_EUcon_20\%) }
$$

In this scenario, both coupled and decoupled CAP pillar 1 payments fully paid by the EU are reduced by $20 \%$ from 2021. However, payments to production first increase from the 2017 level (€ 94.5 million, 18\% of pillar 1 payments) to $€ 102.9$ million for the 2018-2020 period because a recent EU policy decision allows Finland to keep as much as $19.6 \%$ of pillar 1 payments coupled to production. When this $€ 102.9$ million is reduced by $20 \%$ in 2021 , as assumed in this scenario, then $€ 82.3$ million of pillar 1 payments will still be coupled to production from 2021. Thus, the coupled pillar 1 payments will decrease by only $€ 13.3$ million, from the baseline levels in this scenario. The 2021 financing, compared to the 2017 situation is presented in Table 1 regarding the financing shares of Finland and the EU for pillar 2 LFA and agri-environmental payments. Reducing the EU contribution by $20 \%$ implies a reduction in farm payments of $€ 149.6$ million per year, assuming other national financing is unchanged (Table 1 ).

Policy scenario 2 - All CAP pillar 1 payments in 2021 to be decoupled from production

$$
\text { "Cut_EU_con_20\%" }
$$

This scenario involves shifting all funding of coupled CAP pillar 1 payments to decoupled payments 2021. This means that dairy cow and bull premiums, as well as payments per area for oilseed and protein crops currently paid would be abolished in 2021, and funding of approximately $€ 95$ million would be shifted to decoupled CAP pillar 1 payments. This scenario retains the CAP pillar 2 (LFA, agri-environmental) payments, as well as national payments, mostly paid in central and northern parts of Finland in the $C$ support regions, would remain unchanged.

$$
\text { Policy scenario } 3 \text { - A reduction of national payments by } 20 \%
$$

This scenario keeps all other payments though the national payments are reduced from the baseline levels currently paid per litre of milk, head of bovine animals, hectare of oilseed and protein crops in $\mathrm{C}$ support regions (central and northern Finland) by $20 \%$. 
Table 1. Changed EU contributions and total financing (€ million) in pillar 1 and pillar 2 farm support payments in scenarios: 1) A reduction in the EU contribution to agricultural support payments by 20\% (Cut_EUcon_20\%), 2) CAP pillar 1 payments decoupled from production (Decouple pillar1), 3) A reduction of national payments by $20 \%$ (Cut_nat_aid_20\%)

\begin{tabular}{lcccc}
\hline & $\begin{array}{c}\text { Baseline 2017- } \\
\text { (estimated) }\end{array}$ & $\begin{array}{c}\text { 2021- } \\
\text { Cut_EUcon_20\% }\end{array}$ & $\begin{array}{c}\text { 2021- } \\
\text { Decouple pillar } \\
1\end{array}$ & $\begin{array}{c}\text { 2021- } \\
\text { Cut_nat_aid_20\% }\end{array}$ \\
\hline CAP pillar 1, total & 525 & $420(-20 \%)$ & 525 & 525 \\
Decoupled from production & 430.5 & $344.4(-20 \%)$ & 525 & 430.5 \\
Coupled to production & 94.5 & $75.6(-20 \%)$ & 0 & 94.5 \\
LFA, total & 552 & $532.5(-3.5 \%)$ & 552 & 552 \\
EU contribution & 97 & $77.6(-20 \%)$ & 97 & 97 \\
National contribution & 455 & 455 & 455 & 455 \\
Agri-environmental, total & 300 & $274.8(-8.4 \%)$ & 300 & 300 \\
EU contribution & 126 & $100.8(-20 \%)$ & 126 & 126 \\
National contribution & 174 & 174 & 174 & 174 \\
National payments & 330 & 330 & 330 & $264(-20 \%)$ \\
TOTAL & 1,707 & $1,557(-8.3 \%)$ & 1,707 & $1,641(-3.9 \%)$ \\
\hline
\end{tabular}

Market scenario 1 - A Small reduction in the prices for agricultural products from 2021

"Small_price_cut"

This scenario assumes the same agricultural policy and support payments as in the baseline, but assumes a decrease in agricultural product prices from the baseline level, as follows: Cereals $-10 \%$, meat (beef, pork, poultry) $-5 \%$, milk (through 18 different milk products) $-2.5 \%$.

Market scenario 2 - A Significant reduction in the prices for agricultural products from 2021

$$
\text { "Large_price_cut" }
$$

This scenario assumes the same agricultural policy and support payments as in the baseline, but includes a decrease in agricultural product prices from the baseline level as follows: cereals $-20 \%$, meat (beef, pork, poultry) $-10 \%$, milk (in 18 different milk products) $-5 \%$.

\section{The sector model}

In this paper, changes in regional level agriculture throughout Finland under the scenarios outlined above are evaluated using the DREMFIA economic agricultural sector model. The model simulates the production and foreign trade of agricultural commodities, as well as land use (areas for crops and set aside) and production intensity (fertilization, manure use) annually from 1995 up to 2030, and produces a steady state static equilibrium for 2040 and 2050. The model, assuming rational economic behaviour and competitive markets, produces future development paths for agriculture (see Lehtonen 2001 and 2015 for details). As many other agricultural sector models are, this one is based on non-linear optimisation and allows relatively large changes in agricultural production, even after model validation and calibration (shown and discussed in more detail below). There is some tendency towards specialisation of different regions in certain type of production due to explicit optimisation. Nevertheless, the model has been well validated and produces results close to observed development paths of production based on economic and bio-physical data.

Four main areas are included in the model: Southern Finland, Middle Finland, Ostrobothnia (the western part of Finland), and Northern Finland (Fig. 1). Demand and foreign trade are determined at the level of the main regions. The products move between the main regions, to cover the demand of each main region, at a certain transportation cost. The model accurately simulates and reflects agricultural policy, and to achieve this, the main regions are divided into sub-regions according to regional agricultural support payment levels. Production is thus determined at the level of each of the 17 sub-regions (Figure 1 shows 14 regions; 3 small regions are not shown). See Lehtonen $(2001,2015)$ for more details. 
Main areas and support regions

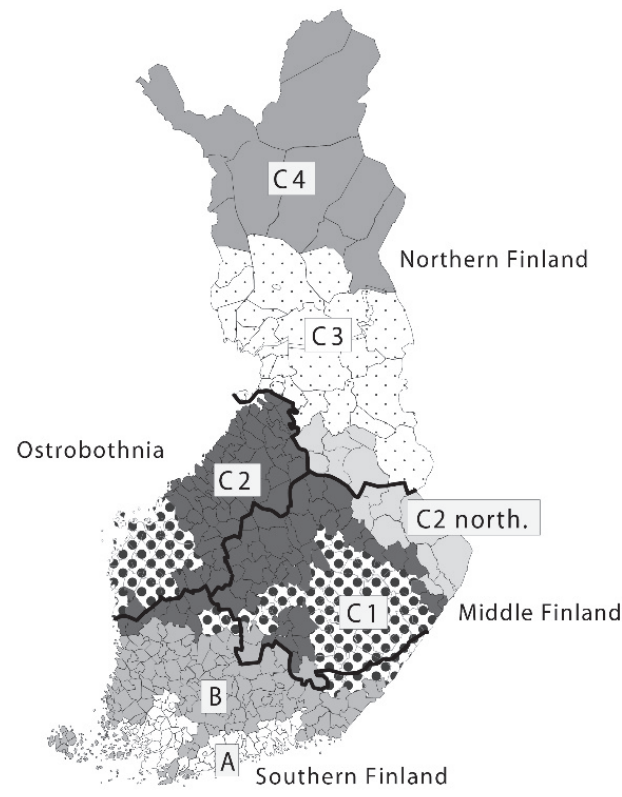

Fig. 1. Spatial aggregation of the DREMFIA sector model. The 4 main regions are divided into support regions ( $A, B, C 1, C 2, C 2$ north, $C 3$, and $C 4$ ) based on agricultural policy: Southern Finland - support regions A, B, C1, and C2; Middle Finland - B, C1, C2, C2 north; Ostrobothnia - C1 and C2; Northern Finland C2 north, C3, and C4

The demand in each main region is covered by the production in its own sub-regions, by transport from other regions, or by imports from abroad. The model is solved so as to achieve the most economic outcome, i.e. the one maximizing producer and consumer surplus. The underlying hypothesis is that producers engage in profit-maximizing behaviour while consumers engage in utility-maximizing behaviour in competitive markets. Assuming decreasing marginal utility of consumers and increasing marginal costs leads to production and foreign trade levels where the marginal cost of supply is equal to market prices. Each region specializes in products that provide the greatest profitability, taking into account resource constraints, profitability of production in other regions, import prices, and consumer demand. The use of different production resources, including farmland, is optimized, taking into account differences in yield levels, technology, and costs of production and transportation. Domestic and imported products are imperfect substitutes; there are differences, even if minor, between the prices of domestic and imported products. Substitution and price elasticities of demand are adjusted in the model calibration in order to validate the model prices with observed prices.

In the model, the prices of nitrogen (N) fertilizer (the same in all scenarios) and crops affect fertilization levels. Crop-specific $\mathrm{N}$ response functions determine the economically optimal $\mathrm{N}$ fertilization and crop yields. As long as manure from livestock is available in the region, less commercial fertilizer is needed to achieve an economically optimal level of fertilization. The phosphorous $(P)$ content of the manure of different animals is also taken into account. A non-negative $P$ balance is ensured in the model, i.e. inorganic fertilisers provide additional $P$ if the $P$ balance turns negative in the model. The milk yield per dairy cow accrues from two main components: (1) a concave quadratic production function with shares of cereals and concentrated feeds as variables; (2) an exogenous increase of the production function over time. If cereals and concentrate feeds are increased, the milk yield increases, but at a decreasing rate when these feeds are increased. This is consistent with the literature on dairy cattle feeding used to specify the production function (Sairanen et al. 2006). While the use of cereals and concentrates in dairy feeding has increased since the 1990s, so has the genetic production potential of dairy cows. The production function and related feeding changes reproduce the observed development of average milk yields very well in Finland for the period 1995-2016.

An important feature of the DREMFIA model is the ability to simulate endogenous technical and structural changes in the dairy sector. A technology diffusion model is used as a sub-module in each year's iteration for specifying investments per dairy farm size category. Invested capital replaces depreciated capital and animal places in each farm size class. The capital depreciation rate is exogenous (8\%) but invested capital is fully endogenously conditioned by the investable surplus (gross margin) and exogenous savings rate, i.e. the share of the gross margin used as investments. Input requirements per animal in each farm size group are derived from Farm Accountancy Data Network (FADN) data. The dairy farm investments are determined each year based on the prices of inputs and outputs, payments coupled to production and endogenous land prices (shadow values of regional land constraints). Thus, structural and technical changes are responsive to changes in revenues and costs. 


\section{Model validation in the baseline scenario}

As already mentioned above, validation of DREMFIA model is not only based on the economic value of production but also on bio-physical feed and nutrient flows. Validation of the DREMFIA model has improved over several earlier applications, especially in terms of nitrogen processes and greenhouse gas emissions (Lehtonen 2013), clover-grass forage production activities and related effects on the milk yields of dairy cows (Lehtonen and Niskanen 2016). Validation of the DREMFIA model has also improved in evaluating the effects of agri-environmental policies (Lehtonen and Rankinen 2015) and the effects of reduced red meat consumption on production, exports and imports (Lehtonen and Irz 2013). Several earlier policy evaluations have improved the accuracy of the model in terms of highly relevant economic and bio-physical relationships.

The baseline is an important point of comparison for the specified scenarios presented above and is set in the model through a multi-phase validation process. For this reason we show the validated levels of production and income during the recent 5-year period. Furthermore, the model outcomes are shown compared to "observed" development in the results section.

Known statistical data from official agricultural statistics for the 1995-2015 period is used extensively, in addition to selected empirical data from research databases for the parameter values for different production functions determining feed use and yield levels of animals, fertilizer use and crop yields (Lehtonen 2001, 2013). Available data on milk quota prices, land rental values, as well as value and quantities of inputs are used in the model validation. Some model-specific behavioural parameters, with few or no exact estimates, or with no occurrences in the literature or known data sources, have been adjusted so that the model very closely replicates the historically observed development of production, land use and prices. Such calibration parameters include (1) substitution and price elasticities of demand, (2) farm-type specific savings rates, and (3) the propensity to invest in larger farms.

Equilibrium properties of the model (increasing marginal costs in terms of production quantity, and decreasing marginal utility for consumers) stabilize the overall production in the model so it is very close to the observed production quantities. Region-specific budget limits imposed on the production support for milk and bovine animals also contribute to the production allocation. The observed and simulated production levels at the national level are given in Table 2. However, when comparing the model outcomes to the observed production development in the 2012-2015 period, some relatively small deviations still occur (Table 2). The grassland area in the model is less than the observed area because horses, lambs and reindeer are not included. Further examples of the model's calibration are available in Lehtonen $(2013,2015)$.

Table 2. Production quantities, crop cultivation areas and farm income in the baseline and in reality ("observed": official agricultural statistics, http://www.luke.fi/en/statistics/ ); 5-year average for the 2012-2016 period. The grassland area is smaller in the DREMFIA baseline than in reality, since horses, lambs and reindeer (users of roughage) are not included.

\begin{tabular}{lcccccccc}
\hline & $\begin{array}{c}\text { Cereals } \\
(1000 \mathrm{ha})\end{array}$ & $\begin{array}{c}\text { Grasslands } \\
\text { (1000 ha) }\end{array}$ & $\begin{array}{c}\text { Milk yield } \\
\text { per cow } \\
\text { (litres) } \\
2011-2015\end{array}$ & $\begin{array}{c}\text { Milk } \\
\text { production } \\
\text { (million } \\
\text { litres) }\end{array}$ & $\begin{array}{c}\text { Beef } \\
\text { (million kg) }\end{array}$ & $\begin{array}{c}\text { Pork } \\
\text { (million kg) }\end{array}$ & $\begin{array}{c}\text { Poultry } \\
\text { meat } \\
\text { (million kg) }\end{array}$ & $\begin{array}{c}\text { Farm income } \\
\text { (million euros) }\end{array}$ \\
\hline DREMFIA & 1208.1 & 547.6 & 8.217 & 2258.5 & 84.7 & 188.2 & 108.5 & 769 \\
Observed & 1154.6 & 690.3 & 8.155 & 2266.7 & 83.8 & 191.1 & 114.8 & 662 \\
$\begin{array}{l}\text { Relative } \\
\text { difference }\end{array}$ & $+4.6 \%$ & $-20.7 \%$ & $+0.8 \%$ & $-1.7 \%$ & $+1.1 \%$ & $-1.5 \%$ & $-5.6 \%$ & $+16 \%$ \\
\hline
\end{tabular}

$\left.{ }^{*}\right)$ The modelled farm income is higher than observed - some miscellaneous cost items are missing in the model.

The savings rate (money left over from the gross margin for investments) and the propensity to invest in larger farms in the dairy sector are exogenous calibration parameters when calibrating the development of the distribution of the number of dairy cows close to reality in different farm size classes: farms with 1-19 cows (t1), farms with 20-49 cows (t2), farms with 50-99 cows (t3), and farms with 100 or more cows (Fig. 2). The development of the distribution of dairy cows in the farm size classes can be calibrated close to the real statistical values using a unique combination of the savings rate and the propensity to invest in larger farms. These parameters are fixed for the entire span of the simulation for the 1995-2030 period. 


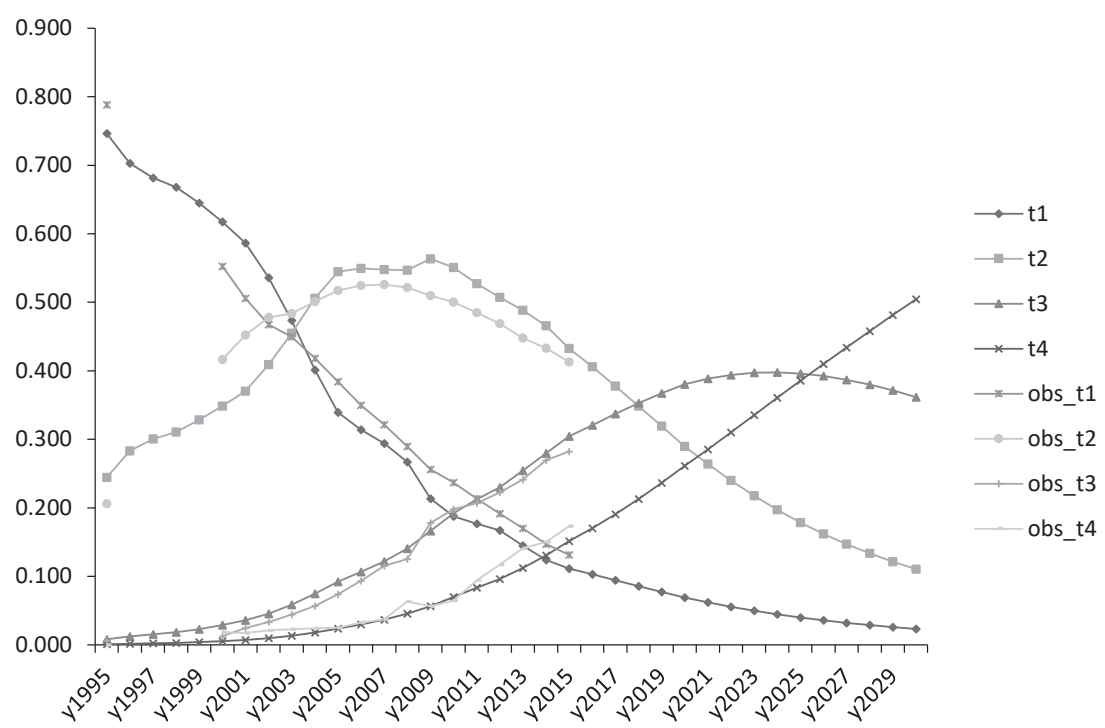

Fig. 2. Simulated development (2000-2029) and observed real development (2000-2015). Source: Official agricultural statistics (www.stat.luke.fi) on the distribution of dairy cows in different farm size classes: farms with 1-19 cows (t1), farms with 20-49 cows (t2), farms with 50-99 cows (t3) and farms with 100 or more cows (t4)

\section{Results and discussion}

Overall milk production in Finland is not affected much by a $20 \%$ cut in the EU CAP budget (Fig. 3, Table 3 ). However, this cut affects CAP payments paid per head for dairy cows ( $€ 550$ per head) in the AB support regions, and per head for suckler cows and bulls in the whole country. These per head payments are higher and they are important in the $A B$ support region, but they are lower and much less important in the $C$ support regions.

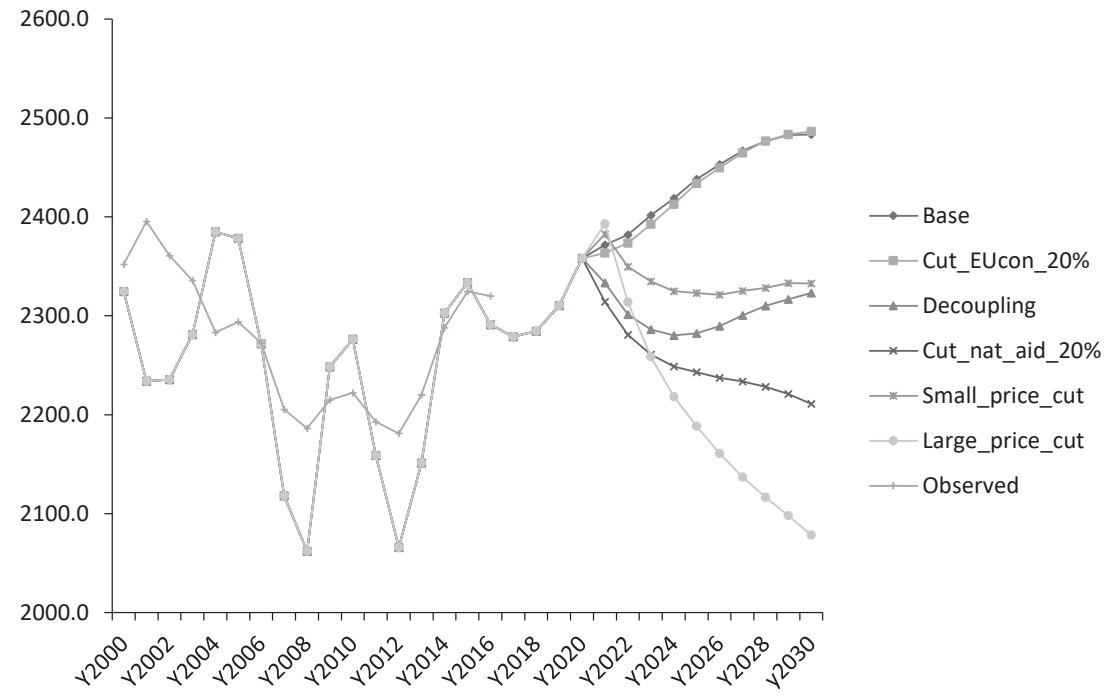

Fig. 3. Simulated milk production (million litres) 2000-2029 in different scenarios vs observed milk production 2000-2016 in Finland

Thus, cutting these payments by $20 \%$ would lead to a reduction in milk production by $5 \%$ already by 2025 in the $A B$ support region in southern Finland (Table 3, Fig. 4). This is because reduced payments coupled to production would negatively affect the gross margins per cow and would also negatively impact investments in dairy farms. At the same time there is an on-going process of structural change in the dairy sector, i.e. a shift of production to larger and more labour efficient cattle houses. Any reduction in investment incentives may have a cumulative effect on production over several years (Lehtonen 2004, Lehtonen et al. 2017). 
Table 3. Simulated livestock production (meat in 1000s tons, milk in million litres), land area under cereal cultivation (1000 ha) and farm income ( $€$ million) in 2025 [observed average values for 2012-2016 are given for comparison]. Region $A B=$ southern Finland, region $\mathrm{C}=$ central and northern Finland (see Figure 1)

\begin{tabular}{|c|c|c|c|c|c|c|}
\hline & Baseline & $\begin{array}{l}\text { Cut EU funding } \\
\text { in CAP by } 20 \%\end{array}$ & $\begin{array}{l}\text { Decouple } \\
\text { CAP pillar } 1 \\
\text { payments }\end{array}$ & $\begin{array}{c}\text { Cut national } \\
\text { payments by } \\
20 \%\end{array}$ & $\begin{array}{l}\text { Small } \\
\text { reduction in } \\
\text { product prices }\end{array}$ & $\begin{array}{l}\text { Large } \\
\text { reduction in } \\
\text { product prices }\end{array}$ \\
\hline $\begin{array}{l}\text { Beef } \\
{[83.8]}\end{array}$ & 82.2 & $\begin{array}{c}79.5 \\
(-3.3 \%)\end{array}$ & $\begin{array}{c}73 \\
(-11.2 \%)\end{array}$ & $\begin{array}{c}75.6 \\
(-8.0 \%)\end{array}$ & $\begin{array}{c}80.5 \\
(-2.0 \%)\end{array}$ & $\begin{array}{c}78.1 \\
(-5.0 \%)\end{array}$ \\
\hline $\begin{array}{l}\text { Pork } \\
{[191.1]}\end{array}$ & 182.7 & $\begin{array}{l}167.6 \\
(-8.3 \%)\end{array}$ & $\begin{array}{c}194.2 \\
(+6.3 \%)\end{array}$ & $\begin{array}{c}176.1 \\
(-3.6 \%)\end{array}$ & $\begin{array}{l}173.8 \\
(-4.9 \%)\end{array}$ & $\begin{array}{c}163.1 \\
(-10.7 \%)\end{array}$ \\
\hline $\begin{array}{l}\text { Poultry } \\
{[114.5]}\end{array}$ & 125.0 & $\begin{array}{c}122.3 \\
(-2.2 \%)\end{array}$ & $\begin{array}{c}125.8 \\
(+0.6 \%)\end{array}$ & $\begin{array}{c}124.2 \\
(-0.6 \%)\end{array}$ & $\begin{array}{c}123.3 \\
(-1.4 \%)\end{array}$ & $\begin{array}{c}118.8 \\
(-5.0 \%)\end{array}$ \\
\hline $\begin{array}{l}\text { Milk - Finland } \\
\text { [2266.7] }\end{array}$ & $2,438.2$ & $\begin{array}{l}2,433.8 \\
(-0.2 \%)\end{array}$ & $\begin{array}{l}2,282.4 \\
(-6.4 \%)\end{array}$ & $\begin{array}{l}2,243.0 \\
(-8.0 \%)\end{array}$ & $\begin{array}{l}2,322.9 \\
(-4.7 \%)\end{array}$ & $\begin{array}{l}2,188.4 \\
(-10.3 \%)\end{array}$ \\
\hline $\begin{array}{l}\text { Milk - AB region: } 520 \\
\text { (2014) }\end{array}$ & 511.2 & $\begin{array}{c}485.3 \\
(-5.1 \%)\end{array}$ & $\begin{array}{c}325.0 \\
(-36.4 \%)\end{array}$ & $\begin{array}{c}530.4 \\
(+3.8 \%)\end{array}$ & $\begin{array}{c}494.5 \\
(-3.3 \%)\end{array}$ & $\begin{array}{c}471.4 \\
(-7.8 \%)\end{array}$ \\
\hline $\begin{array}{l}\text { Milk - C region: } 1,768 \\
\text { (2014) }\end{array}$ & $1,927.0$ & $\begin{array}{l}1,948.5 \\
(+1.1 \%)\end{array}$ & $\begin{array}{l}1,957.4 \\
(+1.6 \%)\end{array}$ & $\begin{array}{l}1,712.6 \\
(-11.1 \%)\end{array}$ & $\begin{array}{l}1,828.4 \\
(-5.1 \%)\end{array}$ & $\begin{array}{l}1,717.1 \\
(-10.9 \%)\end{array}$ \\
\hline Cereal area $[1,154.6]$ & $1,058.6$ & $\begin{array}{c}970.9 \\
(-8.3 \%)\end{array}$ & $\begin{array}{c}1,204.7 \\
(+13.8 \%)\end{array}$ & $\begin{array}{c}1,028.7 \\
(-2.8)\end{array}$ & $\begin{array}{c}981.1 \\
(-7.3 \%)\end{array}$ & $\begin{array}{c}906.4 \\
(-14.4 \%)\end{array}$ \\
\hline $\begin{array}{l}\text { Farm income - Finland } \\
(622)\end{array}$ & 646.2 & $\begin{array}{c}528.2 \\
(-18.3 \%)\end{array}$ & $\begin{array}{c}699.4 \\
(+8.2 \%)\end{array}$ & $\begin{array}{c}560.0 \\
(-13.3 \%)\end{array}$ & $\begin{array}{l}585.4 \\
(-9.4 \%)\end{array}$ & $\begin{array}{c}509.4 \\
(-21.1 \%)\end{array}$ \\
\hline $\begin{array}{l}\text { Farm income }-A B \\
\text { region 2012-2016: NA }\end{array}$ & 256.5 & $\begin{array}{c}194.0 \\
(-24.4 \%)\end{array}$ & $\begin{array}{l}251.2 \\
(-2.0 \%)\end{array}$ & $\begin{array}{l}247.6 \\
(-3.5 \%)\end{array}$ & $\begin{array}{c}230.6 \\
(-10.1 \%)\end{array}$ & $\begin{array}{c}191.0 \\
(-25.5 \%)\end{array}$ \\
\hline $\begin{array}{l}\text { Farm income - C-region, } \\
\text { 2012-2016: NA }\end{array}$ & 389.7 & $\begin{array}{c}334.2 \\
(-14.2 \%)\end{array}$ & $\begin{array}{c}448.2 \\
(+15.0 \%)\end{array}$ & $\begin{array}{c}312.4 \\
(-19,8 \%)\end{array}$ & $\begin{array}{c}354.8 \\
(-9.0 \%)\end{array}$ & $\begin{array}{c}318.4 \\
(-18.3 \%)\end{array}$ \\
\hline
\end{tabular}

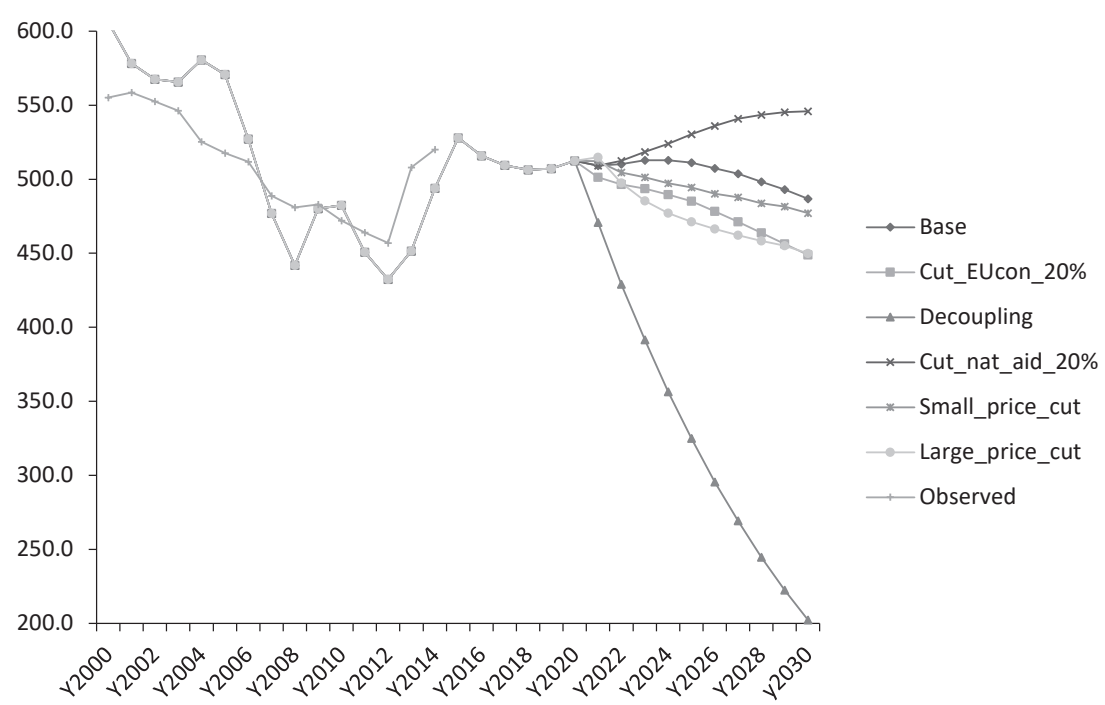

Fig. 4. Simulated milk production (million litres) 2000-2029 in different scenarios vs observed milk production 2000-2016 in the AB support region (southern Finland)

However, this $5 \%$ reduction in milk production is only $1 \%$ of the milk production of the whole country (only approx. $20 \%$ of milk produced in Finland is produced in the $A B$ support region). Overall milk production is reduced by less than $1 \%$ because the reduction in milk production in the $A B$ support region is partly compensated for by a small increase in milk production in the support region C (Figs. 3 and 4), in central and northern Finland, where national payments for milk are coupled to production and unaffected by the EU CAP budget cut. Overall, milk production in the whole country is affected very little (Table 3). 
If the EU CAP payments were all decoupled from dairy and beef production, the reduction in dairy gross margins and investments would be significant. Dairy milk production in the $A B$ support region would decrease by as much as $36 \%$ by 2025 if the CAP payment of $€ 550$ per head for a dairy cow were decoupled (Table 3, Fig. 4). However, in the $C$ support region, where the CAP dairy premiums are not paid, milk production would slightly increase $(+1.6 \%$; Fig. 5) to compensate for part of the production reduction in the $A B$ support regions. However, budgetary limits for the national payments coupled to production would restrict any significant production expansion in region $C$. Consequently, production of milk would decrease by as much as $6 \%$ on a national level.

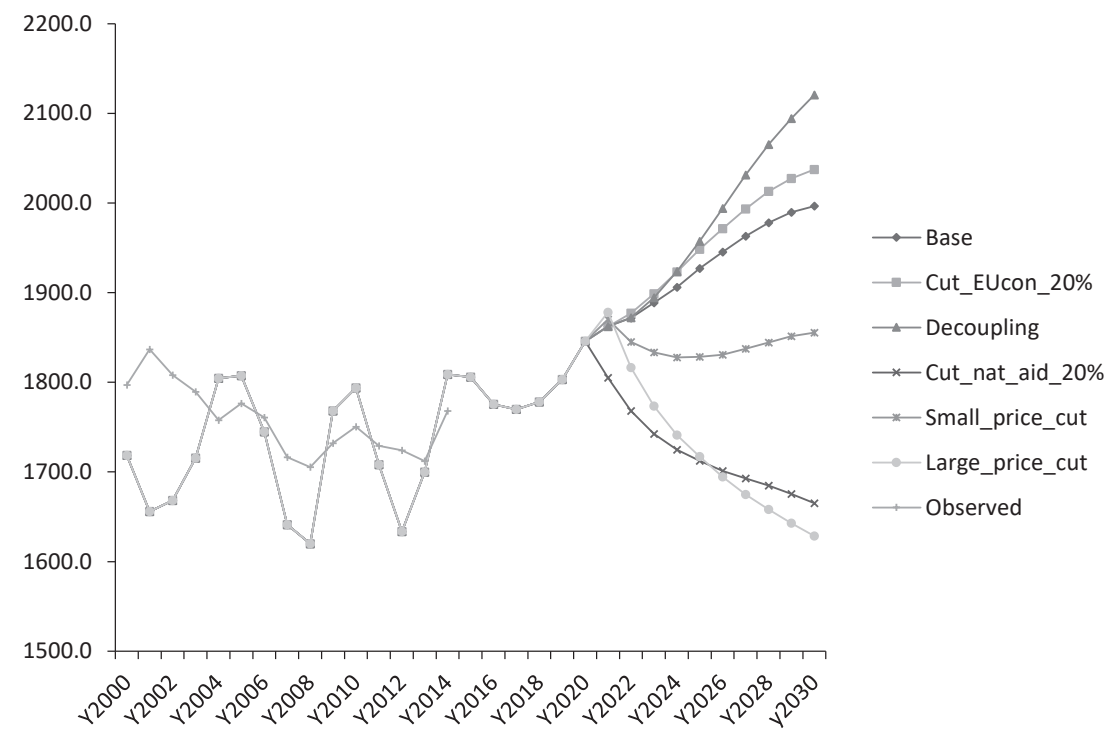

Fig. 5. Simulated milk production (million litres) 2000-2029 in different scenarios vs observed milk production 2000-2016 in the C support region (central and northern Finland)

Beef production would decrease relatively more nationally than milk production if all CAP payments were decoupled from production. Decoupling the CAP bull premiums would affect both specialized bull fattening farms, and some dairy farms which raise bulls as well (Table 3). Decoupling all EU CAP payments from production or reducing national payments by $20 \%$ would have a larger impact on beef production than the market scenarios, with small or large reductions in output prices (Fig. 6).

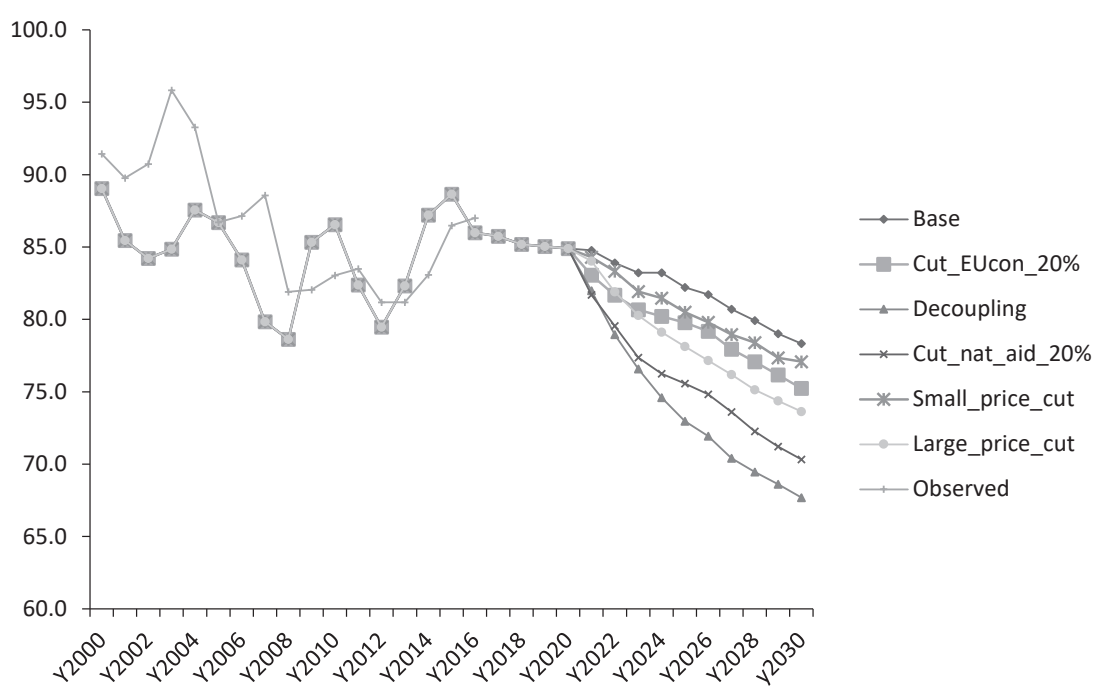

Fig. 6. Simulated beef production (million $\mathrm{kg}$ ) for the whole country in different scenarios 
Reductions in dairy milk and beef production in Finland if support payments are decoupled from production is in agreement with earlier studies. It has already been shown in earlier studies that decoupling support payments for milk and beef production and the implied increase in decoupled payments paid per hectare of farmland, would effectively incentivize exit from dairy and beef production and encourage shifts towards production of cereal and other crops (Lehtonen 2004). This is because such decoupling would imply reduced profitability for investing in dairy and beef production, while higher decoupled payments would increase the gross margins and incomes in crop production, as long as keeping farmland in good agricultural condition is the only criteria for subsidy entitlements (EC 2003). Thus, decoupling CAP payments would also lead to a significantly increased area under cereal production (+13.8\% up to 2025; Table 3, Fig. 7). A stronger supply of cereals, in turn, would increase pork production $(+6 \%)$ but not poultry meat production (Table 3$)$.

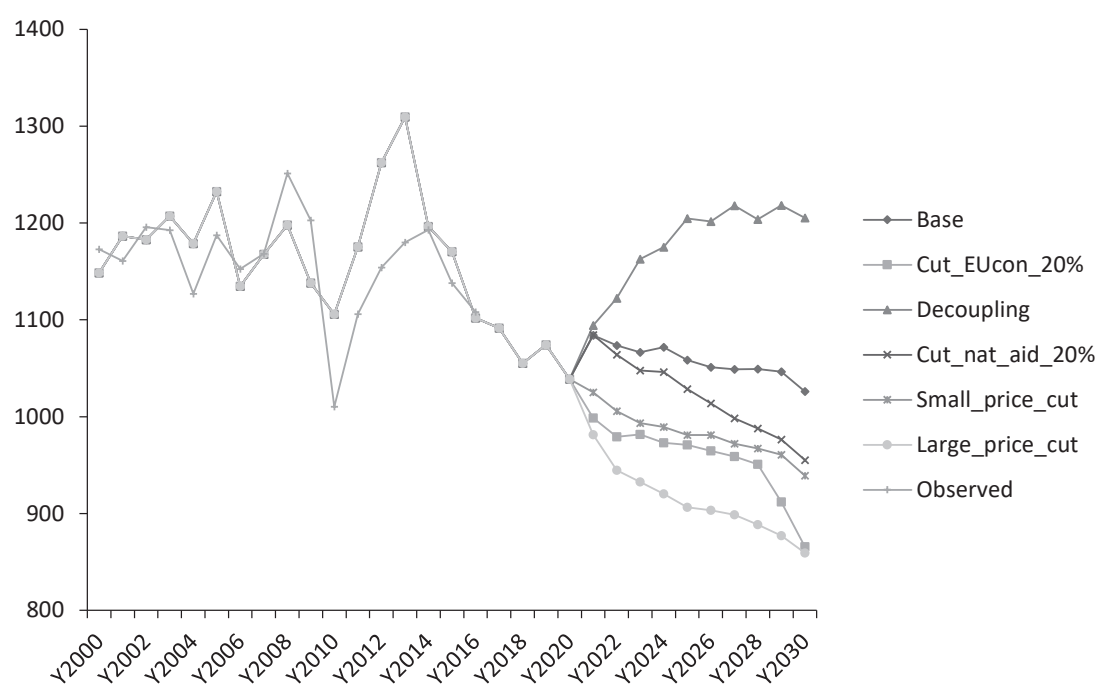

Fig. 7. Simulated cereals production area 2000-2029 in different scenarios vs observed cereals production areas for 2000-2016 in Finland

Decoupling all CAP payments would increase the aggregate farm income in Finland, compared to the baseline $(+8 \%$ by 2025$)$. Increasing welfare and farm incomes and the increased role of market prices as a driving force for production are the traditional arguments, found in a number of model-based studies, which favour decoupling agricultural support payments from production (Balkhausen et al. 2008). Nevertheless, the role and effects of CAP payments coupled to production are not uniform in spatial terms. According to our results, farm incomes would decrease slightly in the $A B$ support region ( $-2 \%$ by 2025$)$ due to rapidly decreasing dairy and beef production, while farm incomes would increase by up to $15 \%$ in the support region $\mathrm{C}$, where the production of milk and beef, and cereals production, would slightly increase. Thus, the production and income effects would be greatly different in southern Finland (support region $A B$ ) compared to elsewhere (Figs. 3-6).

The effects of reducing national agricultural support payments on production and incomes are quite different than in the case of reducing or decoupling EU payments from production. Cutting national payments by $20 \%$ would reduce milk production by $11 \%$ in the support region $C$ and by $8 \%$ nationally, while milk production in the $A B$ support region, with no national payments, would increase by less than $4 \%$ (Table 3). Farm incomes in the $C$ region would decrease by as much as $19 \%$ already by 2025 , while farm incomes would decrease only slightly in the $A B$ region. Cutting national payments by $20 \%$ would nevertheless have little effect on pork, poultry, or cereals production.

It is important to compare the effects of these policy change scenarios on market scenarios where prices are slightly or significantly reduced from 2021 (a small reduction in agricultural product prices; a large reduction in agricultural product prices). Cutting the EU CAP budget by $20 \%$ from 2021 would have smaller effects on agricultural production than a large decrease in market prices, but would have a similar effect on farm incomes, on the aggregate. A small reduction in agricultural product prices would have smaller effects on production than cutting the EU CAP budget by $20 \%$. Thus, cutting the EU farm budget by $20 \%$ can be considered a significant threat to farm incomes, but a relatively less significant threat to the quantity of agricultural production in Finland. This is because decoupled payments have a large direct effect on income but have a much smaller effect on the profitability of investments. The results also suggest that agricultural production in southern Finland (the $A B$ support region) is less sensitive to declines in market prices than agriculture elsewhere in the country. 
This is because of slightly lower production costs, higher crop yields, and larger average farm sizes than in central and northern Finland. However, cutting the EU CAP budget would reduce farm income on average relatively more in southern Finland than in the rest of the country.

The sensitivity of production in central and northern Finland to national payments is obvious. Any significant reduction in national payments would reduce production and income. Similarly, decoupling all EU payments coupled to production would rapidly reduce milk and beef production in southern Finland, where no national payments coupled to milk or beef production are paid. The decrease in milk and beef production in southern Finland could be partially compensated for by increasing production in central and northern Finland if the output prices were sufficiently high. However, budgetary ceilings for national payments effectively mitigate production expansion.

The results from the scenario decoupling EU payments from production show significantly reduced production of milk and beef especially in southern Finland. This is because increasing the land-area-based support, and reducing payments coupled to milk and beef production would effectively reduce the profitability of dairy and beef investments and increase the profitability of crop (cereals) farming, and would raise land prices. Cereals and pork production seem to be somewhat affected by support payments and prices for cereals. High support payments and cereals prices keep less productive farmland in production, while lower support payments and prices will lead to reducing the land area for the production of cereals. Poultry production, which receives no payments coupled to production, and has been driven by strong demand since 2000 , is little affected by cuts in any support payments.

The results show that production in the whole country is somewhat dependent and sensitive to the market prices for milk, meat and cereals, especially in central and northern Finland. It seems that payments coupled to production are still necessary to maintain the current or historical production volumes of milk and beef. This situation has not changed dramatically since early 2000, despite rapidly realized changes in farm structure, due to increased input prices and reduced real prices for farm commodities in the 2000-2016 period. There is still a need to shift milk and beef production to larger farms and thus improve efficiency of production and maintain production motivation despite high costs and fluctuating market prices.

If cuts in the EU CAP budget are realised, policy makers face a challenge to balance short-term income changes and longer-term production development, with differing regional effects, when planning the agricultural policy for the next 2021-2027 CAP period. Maintaining the status quo, i.e. ensuring small changes in all these aspects, seems difficult to achieve. Balancing the production and income effects of a significant EU CAP budget cut without also cutting national payments is difficult - otherwise the effects will be clearly larger in southern Finland than elsewhere in the country. Nevertheless, the results suggest that cutting national payments as well would reduce the aggregate production in Finland even further. The dependency of milk and beef production on payments coupled to production, either from the EU or national budgets, is a root cause of this difficulty which will not be easily solved in the near future if there is no increase in milk and beef prices.

Considering results of the DREMFIA model, or results of any other sector model based on explicit optimisation, one may expect smaller or slower production responses in reality. For example, the observed milk production fluctuated relatively less in the period 2006-2012 than the simulated milk production (Fig. 3). The modelled results are almost entirely based on economic variables, while there are other aspects influencing production decisions in reality. Thus, assuming that economic factors are still strong drivers in reality, the results show the direction of policy effects, rather than the actual production level that will realise. Nevertheless we see our results as consistent with rational economic behaviour and they are worth consideration.

\section{Conclusion}

Our analysis, based on economic modelling of the Finnish agricultural sector, shows the effects of policy and market scenarios on different agricultural production lines and production regions in Finland. The production of milk and meat were little affected nationally by EU CAP budget cuts, but the effects would be significant in southern Finland. A $20 \%$ cut in the CAP budget would reduce farm incomes by $20-25 \%$ in cereals dominated southern Finland, while central and northern parts of the country, which are more dependent on national payments for dairy and beef production, would be less affected. Current legislation does not allow paying national payments coupled to production in southern Finland. Thus, CAP payments play a significant role in southern Finland. 
While more than $80 \%$ of CAP pillar 1 payments are decoupled from production, CAP payments coupled to production are important for dairy and beef farms in southern Finland. Coupled CAP payments are fewer and of less significance in other parts of the country where coupled national payments are paid. Thus, agricultural production and farm incomes in southern Finland seem to be in a weak position if large cuts are made in the EU farm budget.

These regionally diverse effects cause a dilemma for policy makers as current legislation does not allow paying national payments coupled to production in southern Finland. Furthermore, it is hard to see that Finland would have any real opportunities to renegotiate the current policy rules in the EU, which currently faces numerous other challenges. If cuts in the EU CAP budget were realised, it would be difficult to balance regional effects without also cutting national payments. However, cutting national payments as well would reduce the aggregate production in Finland significantly. The dependency of milk and beef production on payments coupled to production is a root cause of this difficulty. This will not be easily solved in the near future, if there is no increase in the real prices of milk and beef.

Our results suggest that dairy and beef production is still dependent on farm payments coupled to production. Decoupling all CAP payments from production, or any significant reduction in national payments coupled to production would affect milk and beef production and farm incomes significantly for the whole country. The effects would be similar to the effects of a relatively large fall in market prices for agricultural commodities. Payments coupled to production are still necessary to maintain the current or historical production volumes of milk and beef. This situation has not changed dramatically since early 2000 , despite rapid changes in farm structure, due to increased input prices and reduced real prices for farm commodities in the 2000-2016 period. Structural change is still much needed in Finnish agriculture. The results support a view that shifting milk and beef production to larger farms will improve efficiency of production and maintain production.

\section{Acknowledgements}

The major part of the costs of this study were covered by financial support from the Ministry of Agriculture and Forestry of Finland, through the "CAP2020"-project.

\section{References}

Balkhausen, O., Banse, M. \& Grethe, H. 2008. Modelling CAP Decoupling in the EU: A comparison of selected simulation models and results. Journal of Agricultural Economics 59: 57-71. https://doi.org/10.1111/j.1477-9552.2007.00135.x

Boulanger, P. \& Philippidis, G. 2015. The EU budget battle: Assessing the trade and welfare impacts of CAP budgetary reform. Food Policy 51: 119-130. https://doi.org/10.1016/j.foodpol.2015.01.004

Dewbre, J, Anton, J. \& Thompson, W. 2001. The transfer efficiency and trade effects of direct payments. American Journal of Agricultural Economics 83: 1204-1214. https://doi.org/10.1111/0002-9092.00268

EC 2003. Council Regulation No 1782/2003 on direct support schemes under the common agricultural policy. Official Journal of the European Union L 270, 29.9.2003.

EU 2017. Commission implementing decision C (2017) 1949 final. http://ec.europa.eu/transparency/regdoc/?fuseaction=list\&n=10\&adv=0\&coteld=3\&year=2017\&number=1949\&version=ALL\&dateFrom=\&dateTo=\&serviceld=\&documentType=\&title $=\&$ titleLanguage $=\&$ titleSearch=EXACT\&sortBy=NUMBER\&sortOrder=DESC. 5 p.

EU 1994. Act concerning the conditions of accession of the Kingdom of Norway, the Republic of Austria, the Republic of Finland and the Kingdom of Sweden and the adjustments to the Treaties on which the European Union is founded. Official Journal of the European Union C 241, 29.8.1994.

EC 2013. Council Regulation No 1307/2013 on direct payments to farmers under support schemes within the framework of the common agricultural policy. Official Journal of the European Union L 347, 20.12.2013.

Eurostat 2017. Crop Statistics. Official EU statistical data. http://ec.europa.eu/eurostat/data/database. Cited November 92017.

Finnish Government 2013. Valtioneuvoston päätös (857/2013) huoltovarmuuden tavoitteista. Annettu Helsingissä 5 päivänä joulukuuta 2013. (Government decision on the security of supply goals 2013. Given in Helsinki on 5 December 2013). https://www. nesa.fi/security-of-supply/objectives/. 9 p. Cited December 32017.

Haas J. \& Rubio E. 2017. Research for AGRI Committee - Possible impact of Brexit on the EU budget and, in particular, CAP funding. European Parliament, Policy Department for Structural and Cohesion Policies, Brussels. http://www.europarl.europa.eu/ RegData/etudes/STUD/2017/602007/IPOL_STU(2017)602007_EN.pdf. Cited February 242018.

Lehtonen, H. 2001. Principles, structure and application of dynamic regional sector model of Finnish agriculture. Academic dissertation. Systems Analysis Laboratory, Helsinki University of Technology. Agrifood Research Finland, Economic Research (MTTL), Helsinki. Publications: 98. 265 p.

Lehtonen, H. 2004. Impacts of de-coupling agricultural support on dairy investments and milk production volume in Finland. Acta Agriculturae Scandinavica, Section C - Economy 1: 46-62. https://doi.org/10.1080/16507540410026135 
Lehtonen, H. 2013. Sector-level economic modeling as a tool in evaluating greenhouse gas mitigation options. Acta Agriculturae Scandinavica, Section A - Animal Science 62: 326-335.

Lehtonen, H. \& Irz, X. 2013. Impacts of reducing red meat consumption on agricultural production in Finland. Agricultural and Food Science 22:356-370.

Lehtonen, H. 2015. Evaluating adaptation and the production development of Finnish agriculture in climate and global change. Agricultural and Food Science 24: 219-234. http://ojs.tsv.fi/index.php/AFS/article/view/51080. Cited November 242017.

Lehtonen, H. \& Niskanen, O. 2016. Promoting clover-grass: Implications for agricultural land use in Finland. Land Use Policy 59 : 310-319. https://doi.org/10.1016/j.landusepol.2016.09.005

Lehtonen, H., Niskanen, O., Karhula, T. \& Jansik, C. 2017. Maatalouden rakennekehitys ja investointitarve vuoteen 2030. Markkinaskenaarioiden vaikutus maatalouden tuotantorakenteeseen (an English abstract: "Structural change and investment needs in Finnish agriculture by 2030"). Luonnonvara- ja biotalouden tutkimus 19/2017. 59 p. ISSN 2342-7639. Cited November 242017. http://urn.fi/URN:ISBN:978-952-326-383-3. (in Finnish).

Lehtonen, H. \& Rankinen, K. 2015. Impacts of agri-environmental policy on land use and nitrogen leaching in Finland. Environmental Science and Policy 50: 130-144. https://doi.org/10.1016/j.envsci.2015.02.001

Matthews, A. 2017. The budgetary context for the CAP after 2020. Cited Novermber 24 2017. http://capreform.eu/the-budgetary-context-for-the-cap-after-2020/

Ministry of Agriculture and Forestry 2017. Ruoka2030: Suomi-ruokaa meille ja maailmalle. Valtioneuvoston selonteko Eduskunnalle 9.2.2017. (in Finnish).

Niemi, J. \& Matthews, A. 2017. Consequences of Brexit on the EU agriculture and food market. In: Niemi, J. \& Väre, M. (eds.) 2017. Finnish agriculture and food sector 2016/2017. URN:ISBN:978-952-326-445-8. p. 51-54.

Niemi, J. \& Väre, M. 2017. Finnish agriculture and food sector 2016/2017. Natural resources and bio-economy studies 49/2017. URN:ISBN:978-952-326-445-8. $91 \mathrm{p}$.

Pietola, K. \& Heikkilä, A.-M. 2005. Switching toward capital-intensive technologies in Finnish dairy farms. Agricultural Economics 33 s3: 381-387. https://doi.org/10.1111/j.1574-0864.2005.00078.x

Ridier, A. \& Jacquet, F. 2002. Decoupling direct payments and the dynamics of decisions under price risk in cattle farms. Journal of Agricultural Economics 53: 549-565. https://doi.org/10.1111/j.1477-9552.2002.tb00037.x

Sairanen, A., Khalili, H. \& Virkajärvi, P. 2006. Concentrate supplementation responses of the pasture-fed dairy cow. Livestock Science 104 3: 292-302. https://doi.org/10.1016/j.livsci.2006.04.009 
